\title{
USING INTERNET RESOURCES TECHNOLOGY FOR EFFECTIVE TEACHING AND LEARNING OF VOCATIONAL AND TECHNICAL EDUCATION
}

OKEH, B. L; LAWAL, N. I. AND BABANGIDA, S. I.

\begin{abstract}
Internet Resources and Technologies have become an integral part of education globally. Computer education and computer in education are two aspects of technology that enhanced Teaching and Learning of Vocational and Technical subjects. In addition, it stressed the importance of teaching and learning of Vocational and Technical Education (VTED) in technology fantasy environment using simulation, interactive, explorative, and subject specific software. It highlighted the impact of using internet and technologies in the unification of some modern teaching strategies, the barriers faced by developing nations, and urges schools to expand their libraries to include ICT unit for universal access. Some recommendations were forwarded which includes: Internet facilities and computers should be provided in all vocational and technical institutions of learning, and powerful broadband servers should be provided that will stand the test of time.
\end{abstract}

\section{Introduction}

Learning is as old as creation. The primitive man started learning things through accidental discoveries, observation and experience. Since then learning has continued and the knowledge base has widen over the years. In each society be it primitive or complex, underdeveloped, developing or developed there exists a system of education. However, the objective techniques and content of education may differ from generation to generation (Harasim, 1996). According to Sheeter and Grant (1999) as long as there have been people, there has been technology, indeed the techniques of shaping tools are taken as the beginning of human culture. It further revealed that technology has been a powerful forced in the development of civilization.

The main reason for designing instruction is to make possible the attainment of set, educational or training objectives. The society in which we live has certain functions to perform in serving the needs of its people. The role of the teacher and students are clearly changing because of the influence of technology in the classroom. The teacher has become the facilitator of knowledge acquisition with the modern technologies. With few key notes, students can explore the world, gaining access to libraries and lots of other resources to obtain the information they are looking for.

\section{The Position of Vocational and Technical Education Today}

It may be necessary here to recast that vocational education means education designed to develop skills, education for people who have chosen their occupations and require further development (Adebute, 1997). Lucey (1997) defined vocation education curriculum as construction of knowledge and work experience systematically developed under the auspices of a school to enable the learner increase his/her control of knowledge and experience. Fafunwa (1990) pointed out that this area of study offers both intellectual reasoning and acquisition of necessary- skills for the technological advancement of nation. National Policy on Education (2004) sees technical education as that aspect of education which leads to the acquisition of practical and applied skills as well as a basis for scientific knowledge. 
This policy emphasized that vocational and technical Institutions should be geared towards the acquisition of practical skills, work attitudes and relevant perceptual framework. Remember that in spite of the learning of the curricula of Technical Schools and Colleges towards producing skilled personnel who will man the world of work, it is unfortunate that these institutions continue to turn out year in, year out mere theoretical technicians for several reasons. Very prominent and outstanding among these reasons is the lack of adequate training facilities for practical acquisition in accordance with the minimum standard requirement set by accrediting bodies (Sheeter \& Grant, 1999). In the same vein; Leech (2002) observed that the output of the middle level technician fall short of expected skills.

Leech (2002) opined that a visit to most Technical Colleges in Nigeria will show a gross inadequacy of training machines, consumables and other equipment in the workshops. However, the introduction of commuter education especially internet resources seems to gain acceptance to support teaching and learning process in view of the gross inadequacy of instructional and infrastructural facilities.

\section{Technology Revolution}

Technology revolution began with the progressive development of the first computers - the hardware of computer-based information in the 1950s. With this development comes the development of software. Operating system software, which tells the computer hardware how to run, has led to the creation of different application programmes for the integration of technology in schools. The increase in the power of computer hardware has allowed software developers to write increasingly powerful programmes that are at the same time increasingly user-friendly. By harnessing the rapidly growing power of microprocessor, application software vastly increased the abilities of teachers and learners. In other words, users should be conversant with the basics of computer and information technology (Lucey, 1997).

\section{Computer Education}

There are two concepts around the use of computer in education- teaching computers and teaching with computers. Teaching computers imply that the content of the curriculum covers many aspects of information and communication technologies (ICT): Computer hardware, software, operating system, application programme, wireless communication, networks, and so on. This represents computer as object of instruction, as courses in computer science and computer literacy programmes. It also covers the social and ethical issues in information technology. With appropriate knowledge and skills, students learn to create high quality layouts at par with global design standard using text, graphic images and sounds (Collis, 1996; Hadad, \& Draxler, 2002).

Teaching with computer begins with computer literacy, thereafter it progresses to acquisition of basic computing operational skills with the knowledge of the devices associated with each operation: input operation, processing operation, storage operation, output operation, and communication operations. The key issues here are the acquisition of desirous skill of office application and presentation tools. This gives the user an edge in any career. Williams and Sawyer (2001) refers to application software as "tools for thinking and working more productively". These tools of practice, for collaboration, for reflection, and places for teaching and learning as Leach puts it, have the potentials of 
helping learners and teachers buildup knowledge in a practical and authentic real-to-life situation. All application programmes are designed to make users more productive at particular tasks. Some productivity software comes in the form of office suits, which bundles several applications into a single large package: Microsoft Office 2007. For example, includes: word, excel, access, outlook express, network, power point and so on. Every year, software developers find way of enhancing their product with new versions; hence we have Microsoft office: 2000, 2003, and 2007, all in an attempt of becoming more user-friendly. Acquiring the knowledge and skills associated with operating system as resource management system in terms of: booting, central processing unit management, file management, task management and formatting, are also very important. Though there are technological skills that teachers and students need to be able to integrate computer into teaching and learning. However. Bransford, Brown \& Cooking (2002) warns that these skills could become hindrance to learning if students spend most of their time picking fonts and colours for multimedia reports instead planning, writing and revising their ideas. Acquisition of computing knowledge and skills can raise economic issues: create job opportunities and reduce unemployment rate; widens the gap between the rich and the poor, between information 'haves' and 'have-not' and as such may become a problem. (Williams \& Sawyer, 2001; Ely, 2002; Okwudishu, 2004).

\section{Computer in Education}

Computer appreciation and application supports education in many ways: word processor for students to compose rapidly is able to produce professional looking text that is relatively easy to read and assess, and produces revised draft without having to rewrite on entire document. Spreadsheet for Mathematics and Science, Database for organizing information can be easily accessed by the use of computer. Before now, slide rule was the symbol of developing technical prowess in engineering, but today, the ability to programme a computer is much more likely to be the appropriate symbol. The dominate mode of teaching large classes is expository, but now computers have been used to enhance expositive teaching by the use of presentation software and vivid computer based demonstration (Achuonye 2011).

ICT can be very effective for teaching and learning Vocational and Technical subjects in many ways: learning from feedback, carefully observing patterns, seeing connections,' working 'with dynamic images, exploring data. According to Leach, (2002) Vocational and Technical activities can be developed through learning technologies-calculators, graphing programmes, function probes. "Vocational and Technical Sup posers" for making and checking conjectures, modeling programmes, for creating and testing models, exploring problems, using equation tools, charts and interactive demonstration strategy. The real revolutionary function of computer in education lies in the novel area of computer-assisted instruction (CIA)- the use of computer system as learning tool CAI software includes tutorials, drill - and- practice programme, simulation, games, discovery and problem solving. It incorporates many other factors of instruction effectively to accommodate different learning styles. Interesting and well-designed programmes, can be motivational and students can spend more time on task. Assessment, diagnosis, and remediation can be built into programmes to help students achieve mastery. Computer enhances individualization of instruction because it can-be programmed to suit individual needs, ability and pace with combined text, graphic images and sound features. Programmes can be designed to encourage students to work in pairs or groups as cooperative learning. A second important aspect of computer as viewed by Achuonye, 
(2011) is the use of computers in schools to manage administrative and clerical tasks; producing texts and-.lesson .plans,-computation of grades and keeping track of students' progress and attendances. All these will create more room for actual teaching.

\section{Teaching Vocational and Technical Education Using ICT}

The overwhelming access to information allows Vocational and Technical Education students to become knowledgeable in different skills through a few mouse clicks. Modern resources connect people and resources together; creating a more linked and networked community - centered environments (Bransford, Brown and Cooking, 2000). Wenger (cited in Hung \& Chen, 2007: 153) focus on two aspects of community -centered learning environments - process and place. In this case, students of vocational and technical subjects can learn as individual and collectively. So they can be encouraged to be responsible for their own learning through self-directed learning skills using computers and Internet as resources to achieve subject specific purposes. Critical thinking; information handling skills; high-level conceptualization; and better problem solving, have been added as factors that are important for effective teaching and learning of vocational and technical education using ICT resources. With challenges, and high expectation, students sensory and cognitive curiosity could be aroused thereby making them responsible for their own learning in a fantasy environment. Interactivity, connectivity and multimedia features of the computer and the Internet provide learners in vocational technical education with motivational choices that promote sense of control.

Realistic graphic simulation with high quality video enables students to observe vocational and technology processes. Industrial processes, role-playing and decisionmaking processes (Wang \& Reeves, 2007; Zhang, 2007). Simulation approach brings reality into the classroom, where conventional practice is out of reach. This represents a move from static model to interactive media that provides visualization and analytic tools which is, challenging the nature of inquiring in Vocational and Technical Education subjects. Laurillard (cited in Cox", 1996) formulates a series of learning interactions that take place when learners are using simulation: checking knowledge and understanding, experimenting, visualizing, reasoning and interpreting. Practice situation can also be modeled. Students can perform experiments on the computer in the absence of real laboratories. Microcomputer-based laboratories (MBLs) represent these applications that are meant as tool in laboratory work. With computer, it becomes much easier to repeat experiments, measure variables. Analyze and represent data graphically (Voogt 1996, Nwojiobi and Nzomiwu, 2006).

Research studies in education points at some teaching strategies that ICT have unified: direct teaching, co-operative learning, mastery learning, and problem-based learning. Students can have lessons presented with presentation software, stimulate situations, build their knowledge, improve their knowledge base, explore authentic issues, work with peers and experts across the globe, select the mode they prefer and work at their own pace (Sadkar and Sadker, 2003).

\section{Learning Center}

Libraries have always been repositories of learning resources. It was mainly print-only, the most cost-effective universally accepted media. With the advent of resource center and the expansion of audiovisual technologies, those resources expanded to include films, 
film strips, records, tapes, video tapes, 3-dimentsional models, projectors, power point, cameras, video cameras, laminating machines. With the advent of computer-based resource, e-library needs further expansion to include hardware, software, websites, and CD-ROMs. Expanding the library to this extent might narrow digital divide; universal access will be of advantage to all students.

\section{Conclusion}

This paper discussed the role of internet resources and technologies as an instructional material for teaching and learning in vocational and technical education in a dynamic environment. It further discussed the information technology revolution and how globalization brought about changes in various professions. Lastly, it discussed the need for vocational and technical education teachers to be up to date with the changing world and make all effort to integrate the modern technologies into classroom instruction, considering the crucial role it can play in developing a lifelong learning culture in vocational and technical education.

\section{Recommendations}

In order to achieve the set goals of using internet resources and technologies in classroom method of teaching Vocational and Technical Education, the following recommendations are proposed.

1. Internet resources and technologies usage should be encouraged and made compulsory at all levels of teacher education curriculum in Nigeria,

2. Computer studies as a subject should be taught right from elementary class to catch them young, especially in basic technology.

3. Government should re-direct it's attention towards on the job training for teachers who do not have computer skills in Vocation and Technical Education and time frame should be given within which every teacher must acquire this skill.

4. Internet facilities and computers should be provided in all vocational and technical institutions of learning, and powerful broadband servers should be provided that will stand the test of time.

5. Stable power supply should be available in the Vocational and Technical Education institutions to make the programme functional and more realistic.

6. Higher institutions offering Vocational and Technical Education learning should create and utilize web sites where they can post information and encourage students at all levels to inculcate the habit of sourcing such information online, instead of the traditional way of spoon feeding them with information. This information involves online application, registration and checking examination results.

7. Corporate organization and individual participation should be encouraged in providing infrastructural facilities and in formation communication. Technology equipment to Vocational and Technical Education institutions of learning at all levels, since government cannot be left alone to meet the educational demands of its people. 


\section{References}

Achuonye, K. A. (2011). Using Computer in Science Class: The Interactive effect of gender. Journal of African Studies and Development, 3 (7): 131-134. Retrieved from http://www.academiciournals.org/JASD.

Adebute, E. (1997). Vocational and Technical Education for Sustainable Development in Nigeria: Paper presented at the first National Conference of Vocational Technical Education. Katsina-Ala. April

Bransford, J. D.; Brovn, A. L. \& Cooking, R. R. (2000). How people learn: brain, mind, experience, and school Washington. D.C.: National Press.

Collis, B A. (1996). Computer in education. In Plomp, T. \& Ely, DP. (Eds) International Encyclopedia of Educational Technology, 16-19 (2 $2^{\text {nd }}$ ed): Pergaman: University Press.

Cox, I. J. (1996). Computer simulations and modeling. In Plomp, T. and Ely, D.P. (Eds) International Encyclopedia of Educational Technology 23-25 (2 ${ }^{\text {nd }}$ ed): Pergaman: University Press.

Ely, D.P. (2002). Trends in Educational Technology. Syracuse, New York: ERIC. Publishers.

Fafunwa, A.B. (1990). Implementation of 6-3-3-4 system of education in Nigeria: A paper presented at the seminar. The 6-3-3-4 system of Education in Nigeria held at Ahmadu Bello University, Zaria, on $12^{\text {th }}-14^{\text {th }}$, February.

Gambari, A. I. (2010). Effectiveness of Computer Assisted Instructional Package in Cooperative Settings on Senior Secondary School Students Performance in Physics in Minna Nigeria. Unpublished PhD Thesis Submitted to the Department of Science Education, University of Ilorin, Ilorin Nigeria.

Hadad, W.D. \& Draxler, A. (2002). The Dynamics of Technologies for Education: Technologies for Education potentials, parameters and prospects. Prepared for UNESCO and AED by Knowledge enterprise Inc.

Harasim, L.M. (1996). Computer Networking for Education. In Plomp, T. and Ely, D.P. (eds.) International Encyclopedia of Educational Technology (2 ${ }^{\text {nd }}$ ed): Pergaman: University Press.

Hung, D. and Chen, D.V. (2007). Content-process authenticity in learning: Implications for identity enculturation and boundary crossing. In Journal of Educational Technology Research \& Development, 55 (2): 147-167.

Leach, J. (2002). Teaching, learning and the digital age. In Moon, B., Mayes, A.S. and Hutchinson (eds.) Teaching, Leaming and the Curriculum in Secondary Schools. NT: The Open University. 
Lucey. (1997). Management information systems. London: Letts Education; Aldine Phce. NaU. : A research council. 199o: National science education standards. Washington, D.C: National Academic Press.

Morrell, D. (1992). The Effects of Computer Assisted Instruction on Student Achievement in High School Biology. Joumal School Science and Mathematics, 92: 177-181.

National Policy on Education, (2004) $4^{\text {th }}$ edition, Lagos, National Research and Development Commission NERDC press.

Nwajiobi E.N. and Nzomiwu, N. (2006). Introduction to computer studies. Onitsha: West \& Solomon Publishing Co. Ltd.

Olele, C. N. (2001). Educational technology and nation building. In Nigeria Journal of Curriculum and Instruction. 10 (5): 27-32.

Olusi, F. I. (2008). Using computers to solve mathematics by junior secondary school students in Edo State Nigeria. College Student Journal, 42 (3): 748-755. Retrieved August 4 2007, from http://www.projectiniiovation.biz/csi.html

Okwudishu, C. O. (2004). ICTs and digital divide: Implications for open learning and distance education in Nigeria. Journal of Education in Developing Area, 13: 202-210.

Paul, S. Y. \& Bahauo, S. (2006) Information and Communication Technologies (ICT's) in teacher education: The way forward. Proceeding of $19^{\text {th }}$ Annual National conference of Nigerian Assotucvirc of Teachers' of Technology (NAIT).

Rajasekar, S. (2010) Innovative Methods Computer Assisted Instruction (CAI). Retrieved $15^{\text {th }}$ DeccBfcier. 2010 from http://www. sekars.net

Sadker, M. P. and Sadker, D.M. (2003). Teachers, schools, and society. NY: McGraw Hill.

Spencer. D- J.and Grant, C.A. (2003). Engagement with Mathematics Courseware in traditional and Online homing environment: Relationship to motivation, achievement, gender, and gender orientation. Unpublished dissertation submitted to the faculty of Graduate School of Emory University, in partial fulfillment of the requirement for the degree of Doctor of Philosophy. Retrieved $10^{\text {th }}$ September, 2011 from $\underline{\text { http://www.des.emory.e/mtp/spence Disseltation20 I }}$ l.pdf.

Tabassum, R. (2004). Effect of computer assisted instruction (CAI) on the secondary school students achievement in science. PhD Thesis, University of Arid Agriculture, Rawalpindi. Retrieved January $2^{\text {nd }} 2009$, from http://www.eprints.hec.gov.plc/350/.

Vcogt, J.M. (1996). Computer-based laboratories. In Plomp, T. and Ely, D.P. (eds.) international Encyclopedia of Educational Technology $\left(2^{\text {nd }}\right.$ ed): Pergaman University press. 
Wang, S. and Reevs, T. C. (2007). The effects of a web-based learning environment on student motivation in a high school earth science course. In Journal Education Technology Research \& Development, 55 (2): 169-192.

Williams, B. K. and Sawyer, S.C. (2001). Using information technology: A practical introduction to computer and communication. N.Y: McGraw Hill.

Zhang, J. (2007). A cultural look at information and communication technologies in eastern education. In Journal Education Technology Research \& Development, 55 (3): 301-314. 